\title{
Ossian in Aotearoa - 'Ponga and Puhihuia' and the Re-Creation of Myth'
}

MARK DERBY

The creation, and re-creation, of myth requires a continuing capacity for invention... The process therefore entails a necessary element of fantasy, often indistinguishable from fraud.

(H.R. Trevor-Roper, The Invention of Scotland ${ }^{2}$ )

'Surely the best of all the Māori stories', is how Margaret Orbell, editor of the magazine Te Ao Hou, described the tale of the impetuous seventeenthcentury lovers Ponga and Puhihuia. ${ }^{3}$ Their illicit romance takes place within a vividly depicted world of desperate canoe voyages, flamboyant dances, cunning deception and hand-to-hand battles, set around the shores of the Manukau Harbour. In addition, the story's wealth of detail, including samples of song-poetry, oratory, archaic custom and tribal history, is today regarded as ethnologically accurate and its Māori-language version is a storehouse of pre-European terms and expressions, including many found nowhere else in print.

Why are Ponga and Puhihuia not better known as mythic, romantic and literary figures today? Dr Orbell suggests the answer in her introduction to Te Ao Hou's publication of their story, which ran in both Māori and English over three successive issues of the magazine in 1963-1964. Its first appearance in full was in 1888 in John White's Ancient History of the Maori, a work fiercely criticised from the outset for poor scholarship and the questionable authenticity of its sources. White, his detractors allege, was inclined to rewrite stories provided by his Māori informants, to merge several versions into one, and at times to supplement them with his own inventions. Dr Orbell herself, however, was in no doubt that 'whether or not the teller of this story actually wrote it down ... it is preserved in substantially the form in which it was originally told'. ${ }^{4}$

Just 13 years after 'Ponga and Puhihuia' appeared in Te Ao Hou, Orbell's endorsement of its essential authenticity was refuted by David Simmons in The Great New Zealand Myth. This profoundly iconoclastic work examined the original sources for published collections of Māori traditions and stated bluntly: 'Te Ponga raua ko Puhihuia is a literary composition by John 
White, a Pākehā. ${ }^{5}$ This paper will test the grounds for these two sharply conflicting propositions, and explore the assumptions that underlie them.

\section{The Ossian Controversy}

As Michael Reilly has noted in his groundbreaking study of John White and his work, the longstanding debate over the authenticity of stories presented by White as traditional Māori narratives, true to their orally transmitted origins, has striking parallels with the most famous literary fake of all, the poems of Ossian (pronounced 'O-sheen'). ${ }^{6}$ When first published in full in 1761 , these long epic poems were claimed by their alleged discoverer, James Macpherson, to be mythic tales from Scotland's distant past, as told by the third-century blind bard Ossian and faithfully passed down over many centuries. This claim was immediately challenged by such redoubtable voices as Samuel Johnson, and vituperative scholarly dispute over the true authorship of the Ossian ballads raged for over a century before they were conclusively established to be largely, although not entirely, composed by Macpherson himself in the style of the ancient bards. Recent scholarship confirms that Macpherson drew on fragmentary material from the early Middle Ages (that is, from a much later period than he claimed) and expanded and adapted it heavily to appeal to the literary taste of his own day.? The debate over the poems' origins, however, had little if any effect on their popularity with the reading public: they were frequently reprinted and widely sold throughout Europe and further afield.

By the 1840s at least one copy had travelled as far as Hokianga, New Zealand, where it was read eagerly by another young would-be poet and folklorist, John White. The son of a Durham blacksmith, White arrived in New Zealand with his family in 1835, at the age of nine. His father's brother was in charge of the Wesleyan mission station on the south side of the Hokianga harbour, and the family settled nearby, near the present-day Hōreke. They found themselves living in isolation from other Europeans, in a world predominantly Māori but also one that Reilly terms a 'hybrid culture', in which many Māori spoke and even wrote in English and in which oral traditions were already disappearing under such powerful colonial influences as literacy. ${ }^{8}$ Young John White had little opportunity for formal education, and his poor grasp of grammar and spelling is evident in his writing over much of his life. However, he had a keen and acquisitive mind and spent much of his youth quizzing local Māori about their customs, history and traditional stories. Determined by the age of 21 on a literary career, he told friends in England: 'We having no variety of books, I spend my evenings in writing rhyme, and translating New Zealand tales, traditions, tales of war, superstitions etc, etc. ${ }^{9}$ In that same year, 1847, White acquired his copy of 
The Poems of Ossian and immediately noted parallels between them and the hundreds of early Māori waiata he had collected.

As a self-taught linguist and ethnographer with only a piecemeal primary education, it is hardly surprising that White's methods of collecting and recording Māori traditions were unsystematic and, even by the standards of his day, somewhat questionable. He often noted down only the main points of a story as it was told to him, writing the full version later from memory. He was prepared to pay, or as he himself put it, to bribe, informants for particularly sensitive information, such as the incantations for religious ceremonies and mākutu, or witchcraft. Especially in the early stages of his collecting career, he communicated with his Māori informants mainly in English, thus relying on their translated versions of their material. ${ }^{10}$

\section{'The Grey Version'}

By his early 20s, White had accumulated an impressive collection of Māori lore, both from the Hokianga where he lived and from the Auckland region, which he had visited several times. He had also acquired a useful knowledge of Māori language and a determination to overcome the limitations of his upbringing by finding outlets for his specialist expertise. ${ }^{11}$ In 1850 he sent samples of waiata to Governor Sir George Grey, well known for his own interest in collecting Māori oral literature. This approach proved fruitful, and Grey engaged White as his translator and personal secretary. Three years later, in 1854, Grey's renowned collection of Māori oral traditions, Nga Mahinga a Nga Tupuna was published, an English translation appearing the following year. This collection included a brief version of Te Ponga raua ko Puhihuia, the story's first appearance in print.

In this short form (referred to hereafter as 'the Grey version'), the story begins by recounting the longstanding state of warfare between the people of Maungawhau (Mt Eden) and of Awhitu (south of the entrance to Manukau harbour). Neither side prevailing, an uneasy peace is agreed between them. It is in this period that Ponga, 'a chief from Awhitu', leads a party of visitors across the harbour to the large pā at Maungawhau, where they are welcomed with speeches and feasting. During the subsequent dancing, both Ponga and Puhihuia, 'the young daughter of the chief' of Maungawhau, contrive to place themselves in the front rank of their respective haka parties, and by this demonstration of their beauty and skill in performing, each conceives a passionate desire for the other.

Since protocol forbids the love-struck aristocrats from approaching each other directly, Ponga's attendant suggests a devious plan by which they can meet the following night. The stratagem succeeds, and the two young people agree to escape together to Ponga's home at Awhitu. As the visitors are preparing to leave Maungawhau, Ponga instructs his followers 
to secretly sabotage the canoes of their hosts to forestall pursuit. During the ceremonies of farewell, Puhihuia's father and Ponga exchange their precious patu pounamu, or greenstone weapons, as symbols of lasting peace between their two peoples. Ponga and his party leave the pā, Puhihuia suddenly flees after them, and all race down to their canoes, 'like a feather drifting before the gale, or as runs the weka which has broken loose from a fowler's snare'. ${ }^{12}$ The people of Maungawhau give chase but, taken thus by surprise, are unable to catch up to the Awhitu party, who 'returned uninjured and joyful to their own country ... carrying off with them the young chieftainess from their enemies, who could only stand like fools upon the shore, stamping with rage and threatening them in vain.' ${ }^{13}$

David Simmons, after an exhaustive investigation of the sources for material such as that collected by Grey, could find no manuscript version of the Ponga and Puhihuia story among Grey's very extensive collections of papers, so, as noted earlier, he determined that the story as originally published in Nga Mahinga is 'a literary composition by John White'. His reference for this unequivocal view is a note in the Auckland Public Library of a meeting between the Pākehā scholar of Māori George Graham Snr and Sir George Grey. ${ }^{14}$ Unfortunately, on separate visits to the library, neither Simmons nor I were able to locate this document.

However, an intriguing manuscript appears among the records of the Wesleyan missionary James West Stack, born in New Zealand in 1835 and raised speaking Māori along with English. His papers include an Englishlanguage account of the Grey version of the story, unfortunately undated, but part of a collection dated $1860-1875 .{ }^{15}$ This account is nearly, but not quite, identical to Grey's, suggesting that it may be a translation of the same story but from a different source. Stack spent the years 1853 to 1859 teaching near the mouth of the Waikato River, within the general tribal area of Ponga's people, and it is conceivable that in this period he learned the story from locals and translated it for his own purposes. ${ }^{16}$

In the absence of conclusive proof of authorship, revealing circumstantial evidence for the origins of the 'Grey version' is provided by the later career and character of John White. After a brief term as Grey's translator and secretary, he went on to hold a succession of official posts, including licensed translator, Land Purchase Commissioner and resident magistrate for the Wanganui region, while maintaining an interest both in collecting Māori lore and in translating and presenting it for a predominantly Pākehā audience. Despite these academic and professional attainments, White seems to have been repeatedly disappointed at his failure to gain or hold senior positions in the civil service and to fully realise his literary ambitions. His attitude is one of the perennial outsider, striving for both financial security and social acceptance but condemned by his lowly origins and meagre formal 
education to remain apart from the more distinguished men of letters whom he emulated and whose company and approbation he sought.

After the failure of a private gold-mining venture in the late $1860 \mathrm{~s}$, White was driven by financial exigency to try to publish more of his work. In 1874 a London publisher released Te Rou, or The Maori at Home, with the hefty Victorian subtitle, a tale exhibiting the social life, manners, habits, and customs of the Maori race in New Zealand prior to the introduction of civilization amongst them. Although named as the author, White stated in a preface: "The tale contained in the present volume is not fiction. Though woven together in the form of a tale, as that most convenient for lifelike presentation, the places mentioned are all real ... the incidents are all true, and have occurred; the personages are all real. ${ }^{17} \mathrm{Te} R o u$ is set in pre-European times in the Hokianga, the region in which White grew up and where he first began collecting Māori traditional knowledge. Although it bears no direct resemblance to the Grey version of 'Ponga and Puhihuia', the story deals with similar themes of love, war and tribal rivalries, but in a much more didactic and longwinded fashion, making frequent lengthy digressions to explain terms and customs to a readership evidently envisaged as non-Māori.

A second book-length work by White, apparently written in the same period as Te Rou, was published in New Zealand in 1940, long after his death. Revenge - A Love Tale of the Mount Eden Tribe, is set, as the title indicates, in the Auckland region, features the characters Ponga and Puhihuia (here called Puhi), and shares many other similarities of setting, plot and language with the Grey version of their story. ${ }^{18}$

There can be no doubt that John White drew on the Grey version, along with other tales from surrounding districts such as Auckland's North Shore, to weave together this rather plodding and discursive narrative of pre-European romance, jealousy and witchcraft.

\section{'The White Version'}

Finally, in 1879, John White achieved his lifelong ambition to compile and write a work on Māori history and custom that would ensure that his name and specialist knowledge would be long remembered. The Ancient History of the Maori was commissioned by the government to preserve, collate and translate the traditional oral records of each of the main tribal groups, and White was appointed editor on the basis of his large personal collection of such material and his acknowledged expertise as a translator and folklorist. However, the ambitious project was plagued by political interference, financial cutbacks, poor administrative oversight and White's own limitations as an archivist and editor. Although the initial concept was for as many as 20 volumes of mythologies and other traditional knowledge, 
the series was cancelled after the first six, plus a supplementary volume of illustrations. While The Ancient History remains an important repository of Māori language and learning, White's unsystematic and highly individual mode of compiling and presenting his material has generated a secondary scholarly industry attempting to disentangle the authentically Māori sources from his own interpolations to them. ${ }^{19}$

Volume IV of The Ancient History gives a version of the story of Ponga and Puhihuia much longer than Grey's ('the White version') and attributed to Ngāti Kahukoka, the tribe traditionally based at Awhitu on the Manukau Harbour. ${ }^{20}$ The story opens in similar fashion to Grey's, although with far more ethnological and historical detail. In a significant variation from the Grey version, Ponga is no longer the leader of the visiting party but instead is identified as 'of junior rank', unable to match his more distinguished companions at preparing elaborate gifts to present to their hosts at Maungawhau. The story proceeds in similar fashion to the Grey version as it recounts the welcome to the visiting party, the midnight meeting between the two young lovers, and their dramatic escape by canoe.

The White version then describes the party's return to Awhitu, where Ponga's tribe is assembled on the shore in dread, knowing that the penalty for the abduction of the young chieftainess must be their own destruction at the hands of their more powerful relations. Puhihuia, a decisive and dauntless character, announces her determination to remain with Ponga even if this means their death, and in response the elderly chief of Awhitu welcomes her to his village regardless of the consequences. When Puhihuia's people send a war canoe to retrieve her, she refuses to return and instead invites her parents and the rest of the tribe to her wedding feast. After prolonged and eloquent debate, the Maungawhau people resolve to suspend hostilities and attend the feast.

However, Puhihuia's mother, as redoubtable a figure as her daughter, commands other women of the tribe to arm themselves and voyage to Awhitu immediately. There Puhihuia again refuses to return home and challenges the younger women to successive single-handed combat, with her fate to be determined by the outcome. Wielding a ceremonial taiaha, she dispatches her opponents one after the other, until her mother is convinced of her determination and agrees to the marriage. The story ends many years later, after the birth of the couple's son, when Ponga disappears while a member of a war party, and his wife and child search for him tirelessly but in vain.

As with the Grey version, the sources for this story are disappointingly slight. The hundreds of folders of White's papers in the Turnbull Library contain no manuscript version of the story as it appears in his Ancient History, but instead two much shorter and fragmentary versions in English. Neither is dated, but from the evidence of the documents with which they 
are filed, they appear to date from around the early 1860s. Both trace the story only to the point where the Awhitu party arrives at Maungawhau. One is very brief and sketchy, while the other, titled 'Maori anecdote of love and war of Auckland and its vicinity', runs to some 18 pages. ${ }^{21}$ Compared with the later, relatively fast-paced, published version, it is remarkably tedious, bombastic and sententious, the opening sentence being unfortunately representative: 'It must not be supposed that the life of a savage like the New Zealander is deficient of the Poetry of life called love, nor would we allow it to be thought that a Maori cannot love with the pure affection which constitutes the moral power of a manly mind. ${ }^{22}$ Together, these manuscripts indicate that around the early 1860 s, as he searched for means to turn his lifetime's accumulation of Māori material into income-generating form, White considered expanding the Ponga and Puhihuia story into a book-length version for a predominantly English-speaking and British-based readership, similar to his later published works Te Rou and Revenge.

\section{Weighing the evidence}

The lack of any manuscript sources for the Grey version (apart from the curious but inconclusive Stack manuscript), make its attribution uncertain. It seems quite possible that John White acquired elements of the Ponga and Puhihuia story during his several trips to Auckland in the 1840s, combined them in the form of a traditional love tale, and presented it to Grey for publication in Nga Mahinga as an authentic orally transmitted narrative. David Simmons found documentary evidence to this effect, but that evidence appears to have subsequently disappeared. At this stage, therefore, an open verdict must be returned as to the authenticity of the Grey version of the story.

A great deal more information is available regarding the origins of the White version, and, while not quite conclusive, the overwhelming weight of that evidence indicates that this is an Ossian-type amalgam of authentic Māori tradition interwoven with White's own literary inventions, themselves based on his wide knowledge of early Māori language and custom. This verdict is supported by the internal evidence of the story's many explanatory digressions, evidently aimed at a non-Māori audience, and by its closer conformity with the conventions of Victorian literary romance than with the less linear Māori oral narrative. ${ }^{23}$ Dr Orbell deduces from its 'high literary quality' (including, presumably, the linguistic qualities of the Māori language version) that the story was indeed related to White by a Māori informant, who had in turn received it through a succession of oral accounts. ${ }^{24}$ However, by the time of the White version's publication in The Ancient History, John White's facility with Māori language, and especially with its archaic forms and vocabulary, was sufficiently advanced that he was very likely capable of 
composing material that even experts could not distinguish from authentically Māori oral narratives. ${ }^{25}$

The differences between the two versions, other than their length and level of detail, are intriguing. It is tempting to speculate that Ponga's demotion from leader of the Awhitu party to a minor member of it, and the running theme of inferior status, reflects White's own preoccupation with his humble origins and his drive to overcome them. In recasting Ponga as the triumphant underdog, White may be revealing his own aspiration to gain honours and status that he felt had been unfairly denied him. Even without venturing on such speculation, the external evidence of White's Ponga and Puhihuia manuscripts - which clearly indicate his intentions to draw on the story for a literary composition - and his known propensity for adapting his source materials for a Pākehā readership, point to White himself as the principal author of his version of this historical romance. ${ }^{26}$

\section{The re-creation of myth}

Dr Orbell greatly admired White's version of Ponga and Puhihuia's deathdefying elopement for 'the intricacy and subtlety of the web of custom and motive which the story reveals, the skill of its telling and the richness of its detail', and her admiration is shared by others who have endeavoured to widen the story's popularity. ${ }^{27}$ The Grey version was adapted for the screen in 1912 by the French filmmaker Gaston Melies, using a cast of Rotorua Māori under the direction of Rev. F. Bennett and the advice and translation services of Māori-speaking historian James Cowan. This intriguing production screened in the US the following year, under the title How Chief Te Ponga Met His Bride, but sadly, does not appear to have survived. ${ }^{28}$

The White version has appeared in print, in English only, in two privately published limited editions (one, from 1961, in blank verse) and in shortened and simplified form in Reed's 1963 Treasury of Maori Folklore, recently republished as the Reed Book of Maori Mythology. ${ }^{29}$ The story is taught today in postgraduate Māori language classes as an outstanding example of early Māori oral literature. ${ }^{30}$ Given this wide acceptance of its qualities as an example of folklore, historical ethnography and pre-European Māori language, the debate around authenticity of 'Ponga and Puhihuia' might seem somewhat irrelevant. How important is it that a story acknowledged as having rare aesthetic and scholarly values may have been largely written by White and not, as he claimed, collected and translated by him?

The question, of course, raises issues far beyond this specific instance. It is useful to return to the Ossian ballads, known to have inspired the young John White, and to consider the similarities and differences between his subsequent faux-archaic creations and those of James Macpherson a century earlier. In either of its two major versions, 'Ponga and Puhihuia' is surely a 
vastly more enjoyable story than the Ossian epics, which have been described in a spirited recent exposé by the English historian Hugh Trevor-Roper as 'totally unreadable' ${ }^{31}$ Ponga and Puhihuia's story, by comparison, is vivid and colourful in its period detail, with compelling action and memorable, albeit stylised, characters. It gains in narrative immediacy from its setting, a mere two centuries before its first publication and not Ossian's improbable fifteen.

The two narratives also appear unlike in their derivation. However much John White may have recreated and augmented the oral material he collected, commonalities in the various versions of the Ponga and Puhihuia story indicate that it was known to pre-European Māori in some form. Orbell probably goes too far in one direction in saying the story 'is preserved in substantially the form in which it was originally told ${ }^{32}$ and Simmonds in the other in classifying it as 'a literary composition by ... a Pākehă' ${ }^{33}$. By contrast, James Macpherson and his collaborators composed the large body of Ossian ballads from stray fragments of Irish song-poems, and reset them in a time and place quite different from the original material.

Both White and Macpherson were motivated by some sense of provincial inadequacy and thwarted literary ambition, but Macpherson was also driven by a Gaelic nationalist impulse that White, the colonial outsider, could not share. What drew him instead to base his literary output on Māori sources was an admiration, shared by contemporaries such as Grey and Domett, for the poetic and narrative qualities of Maori oral literature, the wish to preserve and make it readily available in English, and some notion that doing so would contribute to the great Victorian project of 'elevating' Māori to a primarily European mode of life without entirely sacrificing those native traditions seen as admirable.

White's nostalgic, ahistoric and romanticised accounts of pre-European life appeared in print in New Zealand just as the popular perception of Māori was shifting from barbaric and minatory to noble but doomed. When Macpherson's Ossian poems were first published, Highlanders were undergoing a similar transformation within the British popular imagination. ${ }^{34}$ During White's time, learned Pākehā frequently drew comparisons between Highland Scots and Māori, regarding their relative rates of progress towards 'a state of civilization'. ${ }^{35}$ In other countries as well, national 'myths of origin' of at best questionable authenticity emerged in societies striving to define themselves apart from more powerful and culturally dominant neighbours or colonisers. ${ }^{36}$

The Scotsman and the New Zealand immigrant, therefore, a century and a world apart, were each impelled by a mixture of professional selfinterest and cultural politics, and each chose to re-create the oral mythic literature of an earlier age. Macpherson did so as a conscious act of fraud, 
maintaining that he had discovered the Ossian ballads in their entirety and faithfully translated them. White rewrote, combined, and augmented his found materials, without specifying his contributions to them.

Trevor-Roper, while forensically uncovering how Macpherson and other Scotsmen mythologised their country's history, believes they should be praised rather than condemned for those achievements: 'The myth of the ancient poetry was the beginning of an ideological current which ... would swell the European romantic movement. ${ }^{37}$ The Ossian ballads' evocation of a lost 'northernness' is also thought to have influenced later writers such as Yeats, C.S. Lewis and J.R.R. Tolkien, who were well aware of their origins as an 'imposture'. John White likewise deserves praise for preserving a magnificent tale not elsewhere recorded in print. While he may have heavily embroidered the story he received via a long succession of anonymous Ngāti Kahukoka storytellers, in doing so he can be held to have simply repeated and adapted the process by which they themselves acquired it.

What Foucault has famously termed today's 'author-dominated age' did not obtain in the preliterate world in which Ponga and Puhihuia are said to have lived. ${ }^{38}$ In an era before writing, stories could not belong to a single individual and were disseminated and preserved by 'verbal bearers' whose powers of memory and gifts of expression enabled their listeners to entrust them with the authority of their predecessors in this role. White was strongly drawn to the archaic, anonymous and collective nature of Māori narrative, and in the Ossian ballads he appears to have recognised a model for presenting orally transmitted stories to an age already author-dominated, avant la lettre.

With the help of Trevor-Roper and other scholars who have interrogated the function of a 'myth of origin', the story of Ponga and Puhihuia can therefore be read anew. Orbell and others, both Māori and Pākehā, are not necessarily misguided in their admiration for the dazzling exchange of proverbs and epigrams by which Ponga and his attendant converse while the rest of the pā sleeps. The fragrant gifts conveyed by Awhitu's young people to their Maungawhau relatives, their dancing ('so agile that they could move their bodies as though the waist of each were cut in two'), the bravura oratory of the chief of Awhitu as he risks his people's lives to shelter Puhihuia, the theatrical ceremony of wehenga kai (dividing a feast among various subtribes), and the vividly metaphorical language in which these events are expressed, can all now be read as a faithful and forceful evocation of an Aotearoa long before the arrival of the musket. The subsequent colonial impact ruptured but did not completely sever the chain of oral transmission by which stories like Ponga and Puhihuia's were preserved. In a culture now far more hybrid and less cohesive than White's 
Hokianga, we can be grateful for his link, albeit haphazard, self-interested and improperly acknowledged, in that chain.

1 This study has benefited from the comments made by Michael Brown, Peter Clayworth, Tonga Kārena, James Meffan, Michael Reilly, David Simmons and an anonymous peer reviewer. Nō reira, e ngā kaihanga pai ake, tēnā rā koutou.

2 H.R. Trevor-Roper, The Invention of Scotland: Myth and History, New Haven, 2008, pp.xx.

3 M. Orbell, Te Ao Hou (TAH), 44, 9 (1963), p.16. The story of Ponga and Puhihuia appeared over three successive issues of Te Ao Hou, no.s 44-46, during 1963-64.

4 Ibid.

5 David Simmons, The Great New Zealand Myth, Wellington, p.367.

6 Michael Reilly, 'John White: An Examination of His Use of Maori Oral Tradition and the Role of Authenticity', MA thesis, Victoria University of Wellington, 1985, pp.37-49.

7 Trevor-Roper, pp.108-9.

8 Michael Reilly, 'Secret Writers in Foreign Lands: John White and William Wyatt Gill', New Zealand Journal of History (NZJH), 34, 1 (2000), p.37.

9 Cit. Reilly, 'John White', p.88.

10 Ibid, pp.108-12.

11 Reilly, 'Secret Writers', p.39.

12 Sir George Grey, Polynesian Mythology and Ancient Traditional History of the New Zealand Race, 2nd ed., Auckland, 1885, p.192.

13 Grey, p.193.

14 Simmons, p.367, fn 62.

15 Rev. J.W. Stack, scrapbook, 'The Loves of the Te Ponga and the Maiden Huia', MS Papers 0231, Alexander Turnbull Library (ATL), Wellington.

16 Janet E. Murray, 'Stack, James West' in The Dictionary of New Zealand Biography (DNZB), updated 22 June 2007. Accessed 2 February 2009 at: http://www.dnzb.govt. $\mathrm{nz} /$.

17 John White, Te Rou or the Maori at Home, facsimile ed., Christchurch, 1996, preface, p.v.

18 John White, Revenge - A Love Tale of the Mount Eden Tribe, Wellington, 1940.

19 See, for example, Johannes Andersen, White's Ancient History of the Maori, Wellington, 1947.

20 John White, The Ancient History of the Maori, His Mythologies and Traditions: Tai Nui, facsimile reprint, Christchurch, 1966, IV.

21 John White Papers, MS Papers 0075: 0118, ATL, Wellington.

22 'Maori Anecdote of Love and War of Auckland and Its Vicinity', ibid.

23 For the linear structure of traditional Maori oral narrative, see Agathe Thornton, 'Two Features of Oral Style in Maori Narrative', Journal of the Polynesian Society (JPS), 94, 2 (1985), pp.149-74.

24 Orbell, p.16.

25 David Simmons, personal communication, 16 May 2007.

26 For White's tendency to merge and alter his source narratives see, for example, H.J. Fletcher, ed., Ponga and Puhihuia - From the Original Maori, Hawera, 1927, p.3, which relates a conversation between White and fellow collector of Maori traditions S. Percy 


\section{Journal of New Zealand Studies}

Smith. According to Fletcher, Smith 'suggested that Mr White had added considerably to the original Maori from his own knowledge of Maori life and customs'.

27 Orbell, p.16.

28 Gaston, Melies, Le Autour du Monde de la G. Melies Manufacturing Company, Paris, 1988; Evening Post (EP), 17 September 1912. Information on Melies's work in New Zealand is held at the NZ Film Archive, Wellington, and I am grateful to the Archive's researcher, Louise McCrone, for translation assistance.

29 Privately published editions of the story include Fletcher, ed., and F. Wynn-Williams, ed., Te Ponga Raua Ko Te Puhihuia - The Elopement, Auckland, 1961.

30 It was taught in the course MAOR 406, Victoria University of Wellington, 2006.

31 Trevor-Roper, p.103.

32 Orbell, p.16.

33 Simmons, p.367, fn 62.

34 Trevor-Roper, p.74.

35 See, for example, J. Menzies, MLC, speaking in the Legislative Chamber on the origins of the war then developing in Taranaki, quoted in the New Zealander (NZ), 5 September 1860.

36 See, for example: B. Hernstein Smith, 'Narrative Versions, Narrative Theories', Critical Inquiry (CI), 7 (1980), pp.209-18; A. Dundes, 'Nationalistic Inferiority Complexes and the Fabrication of Fakelore: A Reconsideration of Ossian, the Kinder- und Hausmärchen, the Kalevala and Paul Bunyan', Journal of Folklore Research (JFR), 22, 1 (1985), pp.5-18.

37 Trevor-Roper, p.xxi.

38 Michel Foucault, 'What is an Author?', in Paul Rabinow, ed., The Foucault Reader, New York, 1984, pp. 101-120. 